УДК [338.242: 332.13]: 332.14

\title{
Р.М. Ямилов
}

\section{АДМИНИСТРАТИВНО-ТЕРРИТОРИАЛЬНАЯ РЕФОРМА: ТРАНСФОРМАЦИЯ МЕСТНОГО САМОУПРАВЛЕНИЯ В РЕГИОНАЛЬНОМ КОНТЕКСТЕ (НА ПРИМЕРЕ УДМУРТСКОЙ РЕСПУБЛИКИ)}

В рамках настоящей статьи рассмотрена трансформация местного самоуправления в региональном контексте (на примере Удмуртской Республики) с некоторыми оговорками. Выделены две основные задачи административно-территориальной реформы: объединение муниципальных районов в укрупненные муниципальные районы; поуровневая переконфигурация управленческих процессов на основе функциональной оптимизации. Предложено создание в Удмуртской Республике шести укрупненных муниципальных районов. Выделены смешанные муниципальные районы как результат объединения городских поселений и сельских районов. Выявлено избыточное административно-территориальное управление относительно сельских районов Удмуртской Республики. Предложена укрупненная схема функциональной оптимизации управленческих процессов административно-территориального управления. Разграничены количественная оптимизация и качественная (функциональная) оптимизация административно-территориального управления. Показана необходимость единой цифровой управленческой платформы как основания административно-территориальной реформы. Предложен переход от фрактальной системы управления к антифрактальной системе управления через функциональную оптимизацию управленческих процессов, относительно которых должно строиться административнотерриториальное управление. Показана необходимость соответствия административно-территориальной реформы цифровому управлению. Приведены краткие примеры функциональной оптимизации в отношении региональных образовательных социальных процессов и в отношении региональных сельскохозяйственных социальных процессов. Рассчитано возможное сокращение бюджетных расходов на 5,8 млрд руб. относительно расходов консолидированного бюджета Удмуртской Республики за 2019 г., что составляет 5,99 \% данного бюджета при традиционном варианте региональной переконфигурации управленческих процессов.

Ключевые слова: район, муниципальный район, укрупнения, муниципальный район, регион, административнотерриториальная реформа, административно-территориальное деление, объединение, административнотерриториальное управление, управляемая территория, управление территорией.

DOI: $10.35634 / 2412-9593-2021-31-4-627-638$

Состоявшийся переход в новую общественную формацию (постиндустриальная эпоха, информационное общество, информационализм и т. д.), что окончательно подтвердили пандемийные события, выявил необходимость перестройки общественных отношений в контексте информационализма, в частности в сфере управления большими социальными группами, в том числе государствами. В свою очередь, управление государствами развертывается в определённом пространстве и формализуется в административно-территориальном управление (далее АТУ), которое необходимо актуализировать, поскольку основным инструментом конкуренции больших социальных групп является АТУ, тем самым АТУ должно соответствовать глобальной внешней среде, выражаемой в глобальных вызовах, для оптимального отклика данных групп в целях максимизации выгод и достижении цели существования указанных групп.

Происходящая административно-территориальная реформа ${ }^{1}$ (далее АТР) в Удмуртии является возвратом к одноуровневой системе муниципального уровня, существовавшей до введения двухуровневой системы МСУ в 2003 г., через ликвидацию поселенческого самоуправления и формирование муниципальных округов, фактически являющимися переиначенными районами, существовавшими до 2003 г. На наш взгляд, данная реформа, как и многие другие АТР, не учитывает новую общественную формацию и осуществляется в логике прошлых общественных отношений, следовательно, данная реформа не в полной мере эффективна. Тем самым необходимо рассматривать данную реформу первым, подготовительным, шагом АТР, необходимым для коррекции административнотерриториального управления в контексте информационализма.

\footnotetext{
${ }^{1}$ Происходящее достаточно трудно назвать реформой, так как не происходит существенного изменения административного (содержание МСУ) и/или территориального (форма МСУ) аспектов МСУ, следовательно, происходит ремуниципализация - возврат к ранее существовавшей схеме МСУ.
} 
Рассмотрим позиции исследователей по региональной АТР, которые можно классифицировать относительно контекста исследований:

- исторический контекст, когда исследования обращены и основываются на историческом опыте региональных АТР;

- контекст зарубежных региональных АТР, особенно широкомасштабные исследования региональной АТР, проведены и проводятся украинскими учеными [1-6] и т. д., что вполне объяснимо проводимой АТР 2015-2020 гг. на Украине, требующей научного обоснования и/или подтверждения;

- контекст российских АТР и местного (муниципального) самоуправления (далее МСУ). Отметим, что основной массив российских исследований АТР относится к АТР макроуровня и значительно уступает в объеме украинским исследованиям, особенно в отношении сельских территорий.

Н.М. Великая, А.О. Лазукина исследуют возникшую проблематику в процессе региональной АТР Новой Москвы [7].

По мнению Н.В. Бозо и Г.В. Михеевой, существующее АТУ весьма архаично, раздроблено и бессистемно, что во многом связано с особенностями субъектов РФ [8. С. 73]. Отметим, что данное положение связано с историческим и национальным генезисом формирования российского государства.

Р. Казибеков на примере Дагестана считает, что существующие границы муниципальных образований являются институциональной преградой развития и указывает на необходимость изменения границ [9. С. 99].

По И.Б. Дидиговой АТР районирование Ингушетии советского периода протекала без правильного сочетания национального фактора с экономическими условиями той или иной местности, без учета их особенностей, конкретной исторической ситуации [10. С. 69].

Е.В. Лубенец скептически относится к возможности изменений административнотерриториального деления (далее АТД) России в части объединения или дробления регионов в ближайшие 6 лет $^{2}$, так как возник тренд, направленный на сохранение существующего порядка во всех сферах, в том числе и в области АТУ, но при этом консервация АТД совсем не означает исчезновения точек, в которых его реформирование возможно в более отдалённом будущем [11. С. 60]. Одним из предложений Е. В. Лубенца является проведение на втором уровне АТД ${ }^{3}$ укрупнения районов, через их замену, например, уездами с целью сокращения административного аппарата на основе опыта Свердловской области и Алтайского края по введению управленческих округов, с необходимостью приравнять их к административно-территориальным единицам (далее АТЕ), предоставив их органам соответствующие полномочия с учетом того, что укрупнение административных районов не должно затронуть муниципальные, так как МСУ легче осуществлять на меньшей территории [11. С. 63]. Тем самым государственная власть спускается на первый уровень МСУ и либо существует параллельно МСУ первого уровня, либо государственная власть полностью вытесняет МСУ первого уровня, а МСУ остается только на втором уровне.

Позиция Е.В. Лубенца схожа с позицией О.Б. Глезера, Т.Л. Бородиной, С.С. Артоболевского, которые рассматривают АТР в контексте нормативного регулирования через выделение МО как основы местного самоуправления и АТЕ как основы государственной власти, действующих на одной территории [12]. На наш взгляд, параллелизм государственной власти и МСУ чреват возникновением управленческих конфликтов с последующим управленческим кризисом.

А.А. Позаненко считает, что следствием укрупнения сельских поселений является вымирание деревень, что приводит к уменьшению заселенности территорий, стягиванию населения в более крупные поселения, в основном в города [13].

B.С. Дементьев на примере Псковской области отмечает, что чем будет меньше административных центров, тем разреженней станет система расселения, усилится поляризация населения («стягивание» его в сторону областного центра) [14. С. 22].

Отметим, что по авторским исследованиям коммуникационной доступности и сельскохозяйственных агломерационных процессов, агломерационные процессы протекают на всех уровнях управленческих процессов: мега-, макро-, мезо-, микроуровне и т. д., в том числе уровнях АТД. В российской исследовательской практике и не только в основном исследуют макроуровневые агломерационные процессы. Остальные уровни малоисследованы.

\footnotetext{
${ }^{2}$ Исходя от даты публикации статьи Е. В. Лубенца, в течении 6 лет от 2018(-19) г.

${ }^{3}$ Контекст статьи Е.В. Лубенца предполагает, что под вторым уровнем АТД рассматривается региональный уровень АТД.
} 
Состоится или не состоится региональная и/или районная (муниципальная) АТР, региональные и муниципальные агломерации будут формироваться по объективным основаниям, одним из эффектов которых является вымирание деревень.

В российской практике вполне может быть применен и опыт зарубежных региональных АТР с учетом российских реалий. Например, А.Б. Анасова и А.Т. Исенова в отношении Казахстана АТР связывают с земельно-водной реформой [15]. А.Г. Хачатрян на примере изучения бюджетных расходов расширенного сообщества Шогакат Гегаркуникской области Армении показывает, что изменение состава и структуры бюджетных расходов частично повысило эффективность расходов как результат укрупнения сообществ [16]. Для Н.Н. Питюлича и др. потенциал территориальной общины как социально-экономической категории складывается из природно-ресурсного, человеческого, инфраструктурного потенциалов, которые влияют на функционирование и развитие общин [5. С. 159].

В.С. Кравцив, П.В. Жук в 2011 г. считали, что с учетом низкого ресурсного потенциала большинства существующих в Украине базовых единиц АТУ является оправданным укрупнение мелких АТЕ с ориентацией на минимальную численность населения около 5 тыс. чел. [17. С. 171].

По мнению В.С. Диесперова для сельских громад (общин) главный ресурс эффективности местного самоуправления - территория [18. С. 59]. Для В.Н. Тисуновой и А.А. Резника современное состояние средств связи и транспортного сообщения уже не выступает ограничительным фактором для нового административного деления страны [19. С. 140]. Поэтому главным определяющим фактором должна быть численность населения, определяемая уровнем самодостаточности территории [19. С. 141]. В.И. Шарый, в 2013 г., на примере Украины, считал, что укрупнение районов после становления самодостаточных территориальных сообществ будет содействовать децентрализации власти, поскольку значительная часть полномочий, делегированных органам местного самоуправления, станут их собственными полномочиями [20. С. 38]. Аналогичное мнение выражает и Я.Ю. Белоус [21]. Тем самым, по мнению украинских ученых, возможна децентрализация громад через объединение громад.

Т.Ю. Гусаков считает, что на постсоветском пространстве МСУ рассматривается как институт публичной власти и формируется государственной властью сверху, и в этом заключен парадокс, при этом в Украине же наоборот - предпринята попытка формирования местной инициативы путем добровольной организации органов местного самоуправления [22. С. 156]. Отметим, что:

- по украинской исследовательнице О. Бориславской МСУ - это форма публичной власти, которая реализуется специфическими субъектами - территориальными коллективами и формируемыми ими органами ... [23];

- в 2020 г. в Украине было законодательно выделены и закреплены 1469 территориальных общин;

- до изменений Конституции РФ 2020 г. понятие «публичная власть» в РФ отсутствовало, и деюре МСУ было отделено от государственной власти".

В странах Прибалтики, как отмечают В.А. Шамахов, С.В. Кузнецов, Н.М. Межевич, реформы, направленные на укрупнение единиц местного самоуправления, начались существенно ранее, чем в России [24. С. 12], что, скорее всего, явилось результатом и необходимостью экономии бюджета.

Как показывают Е.Б. Лебедева и И.М. Бусыгина, основные причины для реформ АТД в зарубежных федерациях: 1) этнические, языковые или религиозные расколы; 2) экономическая целесообразность [25. С. 46].

Анализ содержания принятых французских законов позволил Г. В. Семеко выделить три стратегических направления реформы:

- регионализация - укрупнение верхнего звена АТУ, то есть регионов с целью формирования территориальных единиц «европейского размера», повышения их роли в территориальном управлении и эффективности работы;

- укрупнение территориальных сообществ нижнего звена (коммун) на основе формирования сети метрополий (метрополизация), направленное на повышение эффективности работы соответствующих органов местного самоуправления и создание в каждом регионе полюса роста и конкурентоспособности;

\footnotetext{
${ }^{4}$ Введение в Конституцию РФ понятия единой системы публичной власти в корне меняет логику АТР, поскольку коллизия раздельности государственной власти и МСУ устранена, что позволяет создать АТД и АТУ на системных основаниях без «кривых» обходов указанной коллизии. Отметим необходимость научных изысканий государственного и муниципального управления, в том числе АТР, в контексте данного изменения.
} 
- упорядочение распределения полномочий между органами местной власти различного уровня, которое должно обеспечить серьезную экономию государственных расходов [26. С. 22]. При этом, как отмечает Г.В. Семеко, задача децентрализации управления фактически ушла на задний план и французская реформа 2014-2015 гг. направлена не столько на децентрализацию, сколько на рецентрализацию государственного управления за счет расширения полномочий и укрепления роли регионов и метрополий в развитии территорий [26. С. 30].

По мнению А.Н. Швецова, на основании западного опыта реструктурирования муниципальных образований, который представляется весьма полезным для России - главный вектор эволюции структурно-пространственной организации МСУ под влиянием остроты экономических проблем, стоящих перед муниципалитетами: число муниципальных образований уменьшается, а их размеры растут, что прослеживается во многих странах, причем и с федеративным (Канада, Германия и др.), и с унитарным (Франция, Великобритания, Дания и др.) госустройством [27. С. 50], при этом он констатирует, что экономической науке пока почти нечего предложить в качестве теоретически обоснованного и практически приемлемого подхода к рационализации пространственных параметров муниципальных образований [27. С. 60].

А.Н. Швецов выделяет следующие виды реструктруризации МСУ:

- канадские муниципальные слияния [27. С. 50];

- европейское укрупнение муниципалитетов [27. С. 57].

К.Б. Шадыбеков считает, что АТУ часто отражает определенные национальные особенности естественного, исторического, национального и иного характера государства и ключевыми особенностями являются такие, как:

- административный признак - особенность управления и взаимоотношения центра и территорий, степень централизации или децентрализации;

- территориальный признак - способ территориального деления и внутренняя территориальная структура (строение) государства [28. С. 56].

На основании анализа всего спектра мнений по вопросу о будущности регионов РФ В.О. Джораев, Л.А. Тутаева вычленяют по крайней мере три основные концепции реформирования административных структур:

- укрупнение существующих субъектов;

- создание новых крупных базовых единиц с базовым центром;

- «канадская модель», когда РФ делится по линии Архангельск - Киров - Пермь - Екатеринбург - далее Турксиб на обжитой Юг и Юго-Восток и малозаселенный Северо-Запад, и Север, который превращается в особый район со своей спецификой управления, тем самым возрождается Госкомсевер 1990-х гг., наделяемый функциями не федерально-межотраслевого представительства, а органа территориального управления [29. С. 168].

Оценка АТР привела С.И. Евдокимова к следующим выводам: 1) политика объединения «сильного» и «слабого» регионов не даёт положительного эффекта; 2) необходимо осуществлять эффективную региональную политику с децентрализацией финансовых потоков; 3) в случае, если всё же властями будет принято решение об объединении муниципалитетов или укрупнении районов, необходимо быть готовыми к вызванной реформированием АТД поляризации населения и максимально смягчать её негативные социальные последствия (быть готовыми к принятию населения в новых местах, оказывать помощь в обеспечении жильём, работой и т.д.). [30. С. 178].

Основой будущего АТУ субъектов РФ, по мнению В.А. Лапина, В.Я. Любовного, должна стать территориальная организация МСУ [31. С. 33].

По И.Г. Напалковой в России использовались разные формы территориально-государственного устройства: регионально-автономная (XII-XIVвв.); державная (XIV-XX вв.); экономико-технократическая (1922-1930 гг., 1957-1965 гг.); административно-партийная (с 30-х г. ХХ в.) [32. С. 35].

В данной статье представлен авторский сценарий региональной АТР на примере Удмуртской Республики ${ }^{5}$ как частный пример построения оптимального регионального административнотерриториального управления со следующими оговорками:

\footnotetext{
${ }^{5}$ Краткие тезисы данной АТР были изложены автором на конкурсе на замещение Главы МО «Можга» в 2018 г. URL: https://vk.com/wall340159045_21.
} 
- АТР должна планироваться и осуществляться относительно и в рамках российского суверенитета, тем самым АТР должна иметь российский контекст, следовательно, в нашем случае логика построения административно-территориального устройства ограничена пределами региона, то есть АТР рассматривается в контексте региона, особенно в части построения управленческих процессов;

- отграничивание внутристрановых регионов рассматривается в рамках существующих, сложившихся административных границ, хотя наиболее эффективным способом отграничивания, например, с позиции эколого-экономической эффективности, является бассейновая концепция Л.М. Корытного [33-36] и/или авторская гидролого-климатическая концепция [37]. Отметим, что в качестве основы АТД возможно использование физико-географического районирования, например, АТД Удмуртии может быть основана на схеме районирования В.И. Стурмана, в которой выделено 12 физико-географических районов [38];

- в статье не рассматривается правовой механизм реализации АТР;

- предлагаемый сценарий является одним из возможных вариантов АТР.

АТУ можно разделить на два взаимосвязанных блока: управление территорией и управляемая территория [39].

Основанием предлагаемого сценария АТР является авторская концепция коммуникационной доступности, представляющая собой эффективное расстояние деятельности ${ }^{6}$. Относительно современных условий будем использовать:

- производственную коммуникационную доступность - эффективное расстояние производственной деятельности, с диаметром равной 60 км для Европейской части России, формирующая эффективную производственную территорию (зону). Управляемая территория и производственная территория соотносятся как 1:6 [39]. Тем самым базовая управляемая территория, являющаяся кирпичиком АТД, может охватить пространство диаметром 360 км относительно центра формирования управляемой территории. Например, при АТР в контексте российского суверенитета Удмуртская Республика по своим размерам (протяжённость территории с севера на юг 297,5 км, с запада на восток - 200 км [40]) в современных условиях может быть переведена в статус местного самоуправления;

- управленческую коммуникационную доступность, представляющей собой аспектную формализацию информационной коммуникационной доступности;

- эффективное расстояние управленческой деятельности. В настоящее время управленческая коммуникационная доступность из-за взрывного развития коммуникативных технологий безгранична в земных пределах. Соответственно локус управление данной территорией может базироваться в любой пространственной точке. Тем самым необходимость совпадения административного центра региона с географическим центром региона, озвученная Б. Т. Лагутенко [41] в контексте управленческой коммуникационной доступности, потеряла свою актуальность, но при формировании логистики управленческих процессов, например, относительно размещения инфраструктуры образования и здравоохранения, необходимо учитывать географический центр региона и географические центры местных самоуправлений.

Таким образом, в региональной АТР необходимо решить две связанные задачи:

- объединение муниципальных районов в укрупненные муниципальные районы;

- поуровневая переконфигурация управленческих процессов на основе функциональной оптимизации с учетом количества обслуживаемого населения.

На рис. и табл. представлен один из вариантов укрупнения муниципальных районов Удмуртской Республики, в результате чего будет создано 6 укрупненных муниципальных районов, 5 из которых включают в себя города. Отметим, что Юго-Западный и Западный укрупненные муниципальные районы вполне могут быть объединены в один, то есть возможно 5 укрупненных муниципальных районов. В данном случае численность населения во всех предполагаемых укрупненных районах составит $\approx 190$ тыс. чел.

Пять укрупненных районов будут являться смешанными, объединяющими сельские районы и городские поселения, что порождает определенные трудности по причине отсутствия практики таких районов в российском АТУ, то есть необходимы дополнительные научные изыскания относительно смешанных муниципальных районов.

\footnotetext{
${ }^{6}$ Cм.: URL: https://elibrary.ru/download/elibrary_41102936_27447335.pdf (дата обращения: 22.03.2021).
} 
Одной из проблем существующего АТД являются взаимоотношения города и окружающего муниципального района, порождающие административные барьеры и конфликтные зоны, в силу необходимости длительного согласования интересов городских и сельских муниципальных районов, что затрудняет как развитие города, так и развитие муниципального района.

Например, г. Ижевск окружен Завьяловским районом, г. Сарапул фактически окружен Сарапульским районом, примыкание Камбарского района физически отграничено р. Камой, г. Можга окружен Можгинским районом, г. Глазов окружен Глазовским районом.

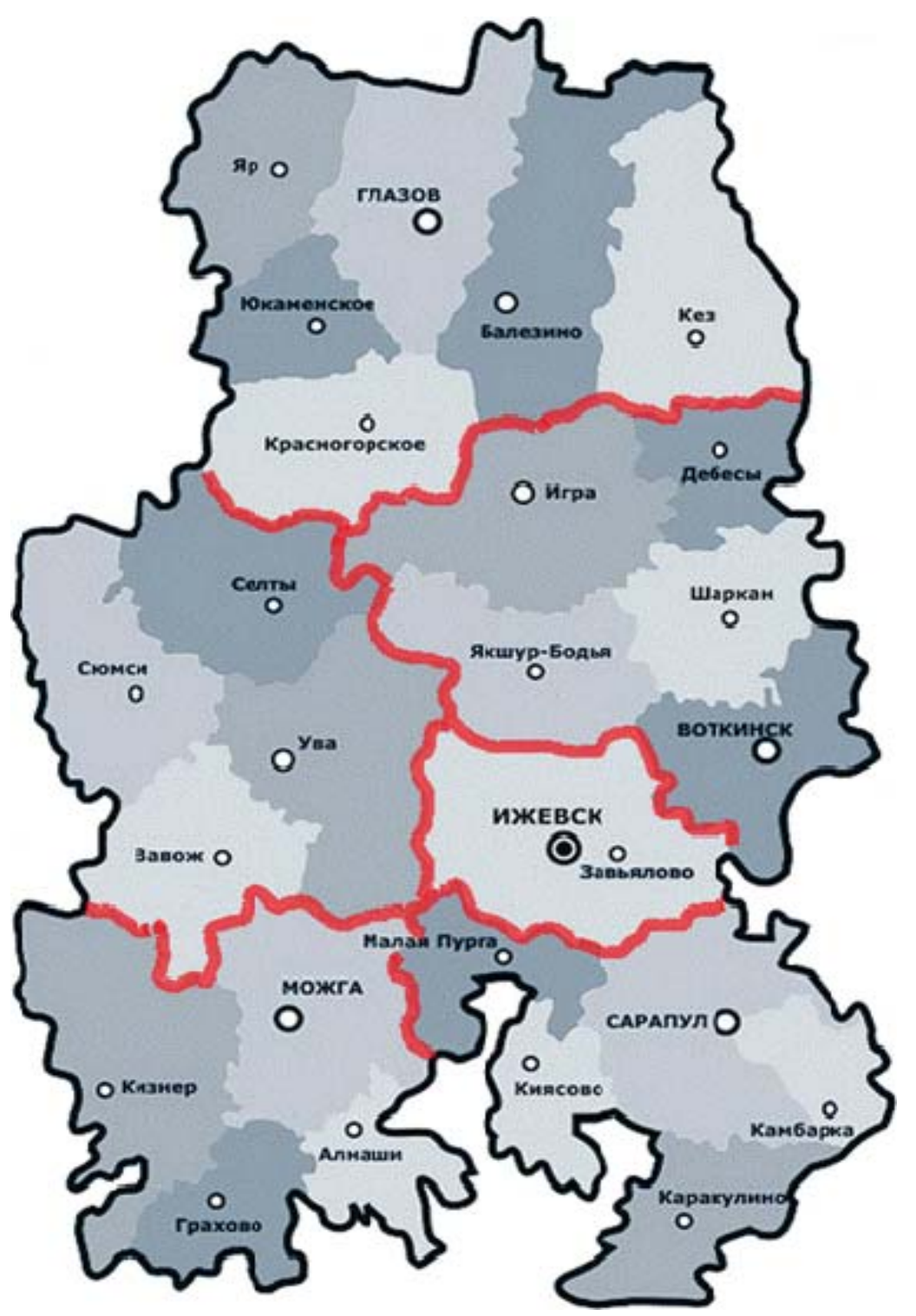

Рис. Схема укрупненных муниципальных районов Удмуртской Республики

Составлено на основе [42].

В случае предлагаемой АТР административные барьеры убираются, соответственно города и сельские территории могут развиваться более планомерно и комплексно.

Отдельно остановимся на формировании Ижевского укрупненного муниципального района, в который войдут Ижевск и Завьяловский район.

В данном случае необходимы две субреформы: объединение Ижевска и Завьяловского района; ликвидация городских районов Ижевска. 
Экономическая эффективность укрупненных муниципальных районов

\begin{tabular}{|c|c|c|c|c|c|}
\hline \multirow[b]{2}{*}{$\begin{array}{c}\text { Укрупненные } \\
\text { муниципальные районы }\end{array}$} & \multirow{2}{*}{$\begin{array}{c}\text { Численность } \\
\text { постоянного } \\
\text { населения на } \\
01.01 .2020, \text { чел. }\end{array}$} & \multicolumn{3}{|c|}{ Бюджетные расходы за 2019 г., тыс. руб. } & \multirow{2}{*}{$\begin{array}{c}\text { Экономия } \\
\text { бюджетных } \\
\text { расходов, тыс } \\
\text { руб. }\end{array}$} \\
\hline & & всего & $\begin{array}{l}\text { на чел, } \\
\text { т. p./чел }\end{array}$ & $\begin{array}{c}\text { всего } \\
\text { в пересчете }{ }^{8}\end{array}$ & \\
\hline Ижевский: & 727616 & 18074277 & 24,8 & 18074277,0 & $\mathbf{0 , 0}$ \\
\hline г. Ижевск & 648146 & 15396017 & 23,8 & & \\
\hline Завьяловский район & 79470 & 2678260 & 33,7 & & \\
\hline Юго-Восточный & 194208 & 6122772,4 & $\mathbf{3 1 , 5}$ & 5649986,6 & 472785,8 \\
\hline г. Сарапул & 95355 & 2331133 & 24,4 & & \\
\hline Камбарский район & 16585 & 609433 & 36,7 & & \\
\hline Каракулинский район & 16402 & 529276 & 32,3 & & \\
\hline Малопургинский район & 33305 & 1138839,4 & 34,2 & & \\
\hline Сарапульский район & 23722 & 949446 & 40,0 & & \\
\hline Киясовский район & 8839 & 564645 & 63,9 & & \\
\hline Юго-Западный: & 117657 & 4728243,4 & 40,2 & 3422930,4 & 1305313,0 \\
\hline г. Можга & 48986 & 1297597 & 26,5 & & \\
\hline Алнашский район & 18242 & 1026544,8 & 56,3 & & \\
\hline Граховский район & 7749 & 396481,6 & 51,2 & & \\
\hline Кизнерский район & 17197 & 985248 & 57,3 & & \\
\hline Можгинский район & 25483 & 1022372 & 40,1 & & \\
\hline Западный & 74353 & 3677892,3 & 49,5 & 2163111,0 & 1514781,3 \\
\hline Вавожский район & 14888 & 767286 & 51,5 & & \\
\hline Селтинский район & 9896 & 731431 & 73,9 & & \\
\hline Сюмсинский район & 11674 & 566841 & 48,6 & & \\
\hline Увинский район & 37895 & 1612334,3 & 42,5 & & \\
\hline Северный: & 186053 & 6573582,6 & 35,3 & 5412737,6 & 1160845,0 \\
\hline г. Глазов & 92334 & 2372586 & 25,7 & & \\
\hline Балезинский район & 29779 & 1087196 & 36,5 & & \\
\hline Глазовский район & 15213 & 621397,8 & 40,8 & & \\
\hline Кезский район & 19433 & 1107901 & 57,0 & & \\
\hline Красногорский район & 8576 & 460154 & 53,7 & & \\
\hline Юкаменский район & 8041 & 403865,8 & 50,2 & & \\
\hline Ярский район & 12677 & 520482 & 41,1 & & \\
\hline Восточный: & 207381 & 7327702,1 & 35,3 & 6033221,4 & 1294480,7 \\
\hline г. Воткинск & 97244 & 2540244,3 & 26,1 & & \\
\hline Воткинский район & 24332 & 966907 & 39,7 & & \\
\hline Дебесский район & 11617 & 608910,6 & 52,4 & & \\
\hline Игринский район & 35608 & 1276690,6 & 35,9 & & \\
\hline Шарканский район & 18094 & 1032811,6 & 57,1 & & \\
\hline Якшур-Бодьинский район & 20486 & 902138 & 44,0 & & \\
\hline Итого & 1507268 & 46504469,8 & & 40756264,0 & 5748205,8 \\
\hline
\end{tabular}

\footnotetext{
${ }^{7}$ Наименования укрупненных муниципальных районов даны условные.

${ }^{8}$ В пересчете применены среднеарифметические бюджетные расходы на чел. по гг. Сарапул, Воткинск, Глазов, Можга равные 29,1 т. p./чел, так как существует тенденция корреляции бюджетных расходов муниципалитета от численности его населения, согласно которой бюджетные расходы на одного человека уменьшаются при росте численности - эффект масштабирования бюджетных расходов. Ижевск исключен из расчета из-за большего размера.
} 
Составлено на основе [42-44].

Осуществляемая Ижевском административная реформа [45] направлена на сокращение аппарата управления, то есть является усеченным вариантом АТР, так как нацелена на количественную корректировку управления территорией при неизменности территориальной компоновки муниципального управления.

Данная реформа является корректировкой аналогового (доцифрового) управления в контексте цифрового мира, которому должно соответствовать цифровое управление, что заведомо приведет к неэффективности реформированного муниципального управления.

На наш взгляд, городские районы Ижевска, которые фактически не являются обособленными МСУ, а являются подразделениями ижевской администрации, подлежат ликвидации, так как в современных условиях и возможностях они становятся избыточными.

Предполагаемая функция городских районов - функция контакт-центра ${ }^{9}$ [45] фактически дублирует многофункциональные центры, которые должны стать органичной частью АТУ на всех уровнях. На наш взгляд, в качестве инструмента непосредственного взаимодействия с населением должны выступать многофункциональные центры.

Результатом укрупнения муниципальных районов при традиционном варианте АТР с укрупнением управляемой территории и без качественного изменения управления территорией, то есть без региональной переконфигурации управленческих процессов возможно сокращение бюджетных расходов на 5,8 млрд руб. относительно расходов консолидированного бюджета Удмуртской Республики за 2019 г., составляющих 96047 млн руб. [46], что составляет 5,99\% данного бюджета.

В настоящее время по данным табл. в сельских районах наблюдается ситуация, когда управление территорией больше, чем управляемая территория ${ }^{10}$ [37], при этом данная ситуация, являясь неоптимальной, может быть стабильной в течении длительного времени, чем и объясняется стабильность существующего АТУ при выявленной, как минимум, выше его неэффективности по финансовым показателям.

Поуровневая переконфигурация управленческих процессов на основе функциональной оптимизации с учетом количества обслуживаемого населения предполагает решение двух подзадач:

- создание единой цифровой управленческой платформы, так как предлагаемая АТР, как и иная другая, возможна при использовании цифровых возможностей и переходом от аналогового управления на цифровое управление. Данная цифровая управленческая платформа должна формироваться в пределах российского суверенитета. Тем самым создание отдельных локальных региональных, муниципальных, учрежденческих цифровых управленческих платформ представляется ошибочным управленческим решением. Таким образом, первоочередной задачей является интеграция существующих цифровых управленческих платформ в единую российскую цифровую платформу;

- переход от территориальной (фрактальной) системы управления к отраслевой (антифрактальной) системе управления через функциональную оптимизацию управленческих процессов [37], относительно которых должно строиться административно-территориальное управление.

Для дальнейших рассуждений выделим уровневое соответствие социальных процессов, которые являются объектом управления социальными системами:

- федеральные социальные процессы, которые осуществимы относительно всей территории РФ;

- региональные социальные процессы, которые осуществимы относительно отдельного субъекта РФ;

- местные (муниципальные) социальные процессы, которые осуществимы относительно отдельного муниципального образования [37].

Таким образом, укрупненная схема функциональной оптимизации управленческих процессов административно-территориального управления выглядит следующим образом:

\footnotetext{
${ }^{9}$ По такому пути в свое время было реформировано Министерство налогов и сборов, когда вместо полноценных налоговых инспекций в большинстве малых районных центрах появились ТОРМы (территориальнообособленные рабочие места).

${ }^{10}$ Ситуация превышения управления территорией над управляемой территорией характерна и для России, и для стран остального мира по причине расширения коммуникационной доступности, поэтому тема АТР актуальна. Отметим, что увеличение количества стран - это эффект политики, в-первую очередь, национальной, а не экономики. По экономическим основаниям количество стран должно сокращаться, и данное сокращение маскируется в различные экономические союзы.
} 
1) классификация всех социальных процессов по уровневому соответствию. Например, здравоохранение и образование должны быть отнесены к федеральным социальным процессам, то есть требуется сквозное АТУ данными социальными процессами, что должно привести к ликвидации всех региональных министерств здравоохранения и образования;

2) создание АТУ соответствующего уровня относительно соответствующих социальных процессов.

В силу вышеуказанных оговорок возможны следующие варианты региональной переконфигурации управленческих процессов:

- традиционный (аналоговый) вариант, в рамках которого укрупнение муниципальных районов влечет за собой укрупнение существующих административно-территориальных органов, что в контексте цифрового управления недостаточно эффективно. Данный вариант является количественной оптимизацией и эффект достигается за счет сокращения административно-управленческого аппарата;

- цифровой вариант, в рамках которого происходит переконфигурация административного управления через функциональную оптимизацию на цифровых основаниях. Данный вариант является качественной (функциональной) оптимизацией и соответствует контексту цифрового управления. Эффект от функциональной оптимизации достигается за счет перерегулирования управленческих процессов относительно социальных процессов на цифровых основаниях, что ведет к большему высвобождению административно-территориального аппарата. Примером данного варианта может быть почти состоявшаяся реформа регионального здравоохранения Удмуртской Республики, когда муниципальный уровень здравоохранения был ликвидирован и больницы стали подчиняться напрямую региональному министерству здравоохранения. Данная реформа эффективно состоится в случае:

- создания единой цифровой управленческой платформы регионального здравоохранения, объединяющая все информационные и управленческие потоки здравоохранения при условии, что данная платформа будет являться частью единой цифровой платформы. Практически все управленческие и информационные процессы должны происходить в цифровой управленческой платформе;

- перераспределение социальных процессов здравоохранения на федеральный уровень.

В силу ограниченности размеров статьи в качестве примера покажем два возможных варианта функциональной оптимизации.

Вариант 1. Функциональная оптимизация АТУ региональным образованием.

Оптимизация АТУ региональным образованием в результате чего подлежит ликвидации муниципальный уровень образования, либо создание межмуниципальных управлений образования с последующим переводом управления социальными процессами образования на федеральный уровень.

В случае административно-территориального реформирования регионального образования возникает вопрос оптимизации инфраструктуры и логистики образовательных процессов, в логике которой встает вопрос укрупнения школ через создание опорных школ, в которых будут обучаться школьники поселений в радиусе 15 км от опорной (базовой) школы.

В данном случае необходимо обеспечить транспортное перемещение школьников поселений до опорной школы и обратно, то есть необходимо создавать образовательную систему, состоящую из опорной школы и гарантированного транспортного доступа.

Оптимизация образовательной инфраструктуры позволит решить вопрос дефицита учителей повысить уровень обучения и управления образовательными процессами и сконцентрировать больше ресурсов, распыляемых сегодня по малокомплектным школам, в частности для оплаты административного персонала школ, для качественного развития образования и повышения оплаты труда учителей.

Таким образом, в АТР необходимо выделить дополнительную задачу инфраструктурной и логистической оптимизации через территориальную и логистическую переконфигурацию инфраструктуру социальных процессов.

Следовательно, существующая практика строительства школ в поселениях неэффективна.

Вариант 2. Функциональная оптимизация АТУ региональным сельским хозяйством.

Оптимизация АТУ региональным сельским хозяйством через ликвидацию муниципальных управлений сельского хозяйства, поскольку сбор информации и регулирование сельского хозяйства возможно в соответствующей цифровой управленческой платформе, либо формирование межмуниципальных управлений сельского хозяйства. При этом формирование территориального разграничения возможно не по административным границам, а на схеме районирования В.И. Стурмана [38], тем самым по соответствующим социальным процессам определяется территориальное разграничение [37]. 


\section{СПИСОК ЛИТЕРАТУРЫ}

1. Иртищева И.А., Хвесик Ю.М., Стегней М.И. Децентрализация системы управления в обеспечении устойчивого развития сельских территорий // Международный научно-производственный журнал «Экономика АПК». 2015. № 4 (246). С. 64-70.

2. Когут И.А. Обеспечение социально-экономического развития сельских территорий в современных условиях // Науковий вісник: фінанси, банки, інвестиції. 2012. № 3 (16). С. 33-40.

3. Куриляк М.Ю. Парадигма реформування адміністративно-територіального устрою України на рівні NUTS-1 // Вестник экономической науки Украины. 2018. № 1 (34). С. 70-76.

4. Лисовая Т.А. Совершенствование административно-территориального устройства Украины // Научный вестник Полесья. 2015. № 2 (2). С. 53-58.

5. Питюлич Н.Н., Машико К.С., Кудак К.М., Пауш М.М. Потенциал территориальной общины: особенности формирования и развития // Молодий вчений. 2016. № 4 (31). С. 155-160.

6. Рыльская В.В. Развитие регионального самоуправления в контексте эволюции представлений о территориальном делении власти в Украине // Публічне урядування. 2016. № 1 (2). С. 38-48.

7. Великая Н.М., Лазукина А.О. Административно-территориальные реформы МСУ в Новой Москве: решения власти и оценки населения // Вестн. РГГУ. Серия: Философия. Социология. Искусствоведение. 2019. № 4 (19). C. 48-60.

8. Бозо Н.В., Михеева Г.В. Альтернативный вариант административно-территориального деления в РФ // Идеи и идеалы. 2014. Т. 2. № 2 (20). С. 70-79.

9. Казибеков Р. Изменение административно-территориальных границ Республики Дагестан как необходимая институциональная реформа // Механизм реализации стратегии пространственного развития государства: сб. материалов VIII Междунар. науч.-практ. конф. / под ред. А.М. Эсетовой; Дагестанский гос. техн. ун-т. 2016. С. 97-99.

10. Дидигова И.Б. Районирование как реформа административно-территориального обустройства Северного Кавказа в начале XX века (на примере Ингушетии) // Рефлексия. 2007. № 2. С. 65-69.

11. Лубенец Е.В. Основные тенденции развития АТД России: настоящее и будущее // Псковский регионологический журнал. 2019. № 1 (37). С. 56-64.

12. Глезер О.Б., Бородина Т.Л., Артоболевский С.С. Реформа местного самоуправления и административнотерриториальное устройство субъектов РФ // Изв. Российской академии наук. Серия географическая. 2008. № 5. C. 51-64.

13. Позаненко А.А. Последствия укрупнения сельских поселений: взгляд снизу // Вопросы государственного и муниципального управления. 2015. №1. С. 168-184.

14. Дементьев В.С. Оптимизация административно-территориального деления Псковской области: оценка последствий // Географический вестник. 2019. № 1 (48). С. 14-25.

15. Анасова А.Б., Исенова А.Т. Мемлекеттік Думадағы қазақ депутаттары және жер-су мәселесі // Вестник КГПИ. 2015. № 2. С. 7-12.

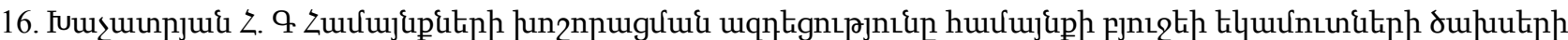

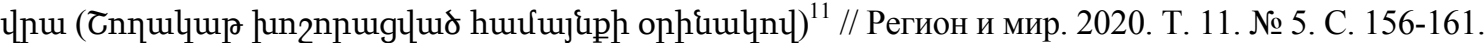

17. Кравцив В.С., Жук П.В. Вопросы реформирования административно-территориального устройства в Украине и местное самоуправление // Экономическое возрождение России. 2011. № 4 (30). С. 169-174.

18. Диесперов В.С. Сельские общины и административно-территориальные реформы // Междунар. научн. производств. журн. «Экономика АПК». 2015. № 1 (243). С. 56-63.

19. Тисунова В.Н., Резник А.А. Региональные аспекты административно-территориальной реформы в Украине // Научн. вестн. Одесского национального эконом. ун-та. 2014. № 5 (213). С. 137-148.

20. Шарый В.И. Задачи и принципы трансформации системы местного самоуправления в условиях реформы административно-территориального устройства Украины // Региональные исследования. 2013. № 1 (39). C. $35-40$

21. Белоус Я.Ю. Проблемы и перспективы развития территориальных громад в Украине // Тр. БГТУ. Серия 5: Экономика и управление. 2017. № 2 (202). С. 91-97.

22. Гусаков Т.Ю. Муниципальная реформа 2015 года в Украине: реализация и первые итоги // Крестьяноведение. 2019. Т. 4, № 2. С. 138-159.

23. Бориславська О. Місцеве самоврядування як форма децентралізації та гарантія демократичного політичного режиму (недоступная ссылка) // Вісник Львівського університету. Серія юридична. 2011. Випуск 52.

24. Шамахов В.А., Кузнецов С.В., Межевич Н.М. Реформирование местного самоуправления: опыт государств Прибалтики и его значение для России // Управленческое консультирование. 2021. № 1 (145). С. 10-19.

\footnotetext{
11 Хачатрян А. Г. Влияние расширения сообществ на бюджетные доходы и расходы сообщества (по модели расширенного сообщества Шогакат).
} 
25. Лебедева Е.Б., Бусыгина И.М. Административно-территориальное деление в РФ: реформы и фактор политического режима // Полис. Политические исследования. 2012. № 3. С. 45-62.

26. Семеко Г.В. Территориальная реформа 2014-2015 гг. во Франции // Федерализм. 2017. № 3 (87). С. 19-32.

27. Швецов А.Н. Пространственные параметры муниципальных образований: постсоветские «качели» и экономические основания рационализации // Российский экономический журнал. 2007. № 3. С. 36-62.

28. Шадыбеков К.Б. Административно-территориальная реформа в Кыргызской Республике: концептуальноправовые подходы реформирования // Вестн. Воронеж. гос. ун-та. Серия: Право. 2018. № 4 (35). С. 55-66.

29. Джораев В.О., Тутаева Л.А. Анализ результатов первого этапа реформы административно-территориального управления Российской Федерации // Изв. Оренбургского гос. аграрного ун-та. 2009. № 1 (21). С. 166-170.

30. Евдокимов С.И. Оценка административно-территориальных реформ как способ повышения экономической эффективности территорий // Псковский регионологический журнал. 2012. № 13. С. 176-179.

31. Лапин В.А., Любовный В.Я. Реформа местного самоуправления и административно-территориальное устройство России. Москва: Дело, 2005. 240 с.

32. Напалкова И.Г. Эволюция территориальных преобразований в России // Регионология. 2009. № 3 (68). С. $28-35$.

33. Корытный Л.М. Административно-территориальное деление России: бассейновый вариант // География и природные ресурсы. 2006. № 4. С. 29-37.

34. Хатухов А.М., Берова Ф.Ж. Бассейновый принцип административно-территориального деления как альтернатива современному расселению этнических групп населения Кабардино-Балкарии // Alma mater (Becтн. высш. шк.). 2020. № 11. С. 60-71.

35. Корытный Л.М. Бассейновая концепция в природопользовании. Иркутск: Изд-во Ин-та географии СО РАН. 2001. $163 \mathrm{c}$

36. Корытный Л.М. О необходимости и возможности реформирования административно-территориального деления России // Сб. докл. XXV сессии МАРС / под ред. С.С. Артоболевского, Л.М. Синцерова. Москва: Институт географии РАН, 2008. С. 5-15. URL: http://www.terrus.ru/sources/sborn/id17.shtml (дата обращения: 22.03.2021).

37. Ямилов Р.М. Административно-территориальная реформа: концептуальные основания переконфигурации российского пространства // Экономические науки. 2021. № 3 (449). Вып. 72. С. 35-46.

38. Кашин А.А., Стурман В.И. Уточненная схема физико-географического районирования и количественная характеристика ландшафтов Удмуртии // Вестн. Удм. ун-та. Серия «Биология. Науки о Земле». 2012. № 4. C. $104-114$

39. Ямилов Р.М. Административно-территориальная реформа: базовое соответствие территориального управления и управляемой территории // Изв. высш. учебных заведений. Серия «Экономика, финансы и управление производством». 2019. № 3 (41). С. 45-51.

40. URL: http://www.udmurt.ru/region/ (дата обращения: 22.03.2021).

41. Лагутенко Б.Т. Как обустроить «ассиметричную» Россию? 24.10.2000. URL: https://www.ng.ru/ideas/2000-1024/8 assim.html (дата обращения: 22.03.2021).

42. Муниципальные образования. URL: http://www.udmgossovet.ru/interaction/local/regions/ (дата обращения: 22.03.2021).

43. База данных показателей муниципальных образований. URL: https://www.gks.ru/dbscripts/munst/munst94/ DBInet.cgi (дата обращения: 22.03.2021).

44. Численность постоянного населения Удмуртской Республики на 01.01.2020. URL: https://udmstat.gks.ru/storage/mediabank/Числ_MO_2020.pdf (дата обращения: 22.03.2021).

45. «Главная задача - не потерять управляемость в погоне за красивыми цифрами» URL: https://www.kommersant.ru/doc/4740647 (дата обращения: 22.03.2021).

46. Исполнение консолидированного бюджета Удмуртской Республики по статьям доходов и расходов за 2019 год. (по данным Минфина УР). URL: https:/udmstat.gks.ru/storage/mediabank/исполн_12.pdf (дата обращения: 22.03.2021).

Поступила в редакцию 26.05.2021

Ямилов Рамиль Могатович, кандидат экономических наук, доцент

Сарапульский политехнический институт (филиал)

ФГБОУ ВО «Ижевский государственный технический университет имени М.Т. Калашникова» 427960, Россия, Удмуртская Республика, г. Сарапул, ул. Труда, 8

E-mail: jaramo@mail.ru 


\title{
R.M. Yamilov
}

\section{ADMINISTRATIVE-TERRITORIAL REFORM: TRANSFORMATION OF LOCAL SELF-GOVERNMENT IN THE REGIONAL CONTEXT (A CASE STUDY OF THE UDMURT REPUBLIC)}

\author{
DOI: $10.35634 / 2412-9593-2021-31-4-627-638$
}

Within the framework of this article, the transformation of local self-government in the regional context (on the example of the Udmurt Republic) is considered with some reservations. Two main tasks of the administrative-territorial reform are identified: the unification of municipal districts into enlarged municipal districts; and the level-by-level reconfiguration of management processes based on functional optimization. It is proposed to create six enlarged municipal districts in the Udmurt Republic. Mixed municipal areas are identified as a result of the combination of urban settlements and rural areas. Excessive administrative-territorial management in relation to rural areas of the Udmurt Republic is revealed. An enlarged scheme of functional optimization of administrative processes of administrative-territorial management is proposed. Quantitative optimization and qualitative (functional) optimization of administrativeterritorial management are distinguished. The necessity of a single digital management platform as the basis of administrative-territorial reform is shown. The transition from a fractal management system to an antifractal management system is proposed through the functional optimization of management processes, in relation to which administrative and territorial management should be built. The necessity of compliance of administrative-territorial reform with digital management is shown. Brief examples of functional optimization in relation to regional educational social processes and in relation to regional agricultural social processes are given. The possible reduction of budget expenditures by 5.8 billion rubles relative to the expenditures of the consolidated budget of the Udmurt Republic for 2019 is calculated, which is $5.99 \%$ of this budget in the traditional version of the regional reconfiguration of management processes

Keywords: district, municipal district, consolidation municipal district, region, administrative-territorial reform, administrative-territorial division, association, administrative-territorial administration, managed territory, territorial administration.

Yamilov R.M., Candidate of Economics, Associate Professor

Sarapul Polytechnic Institute (branch) of Izhevsk State Technical University named after M.T. Kalashnikov Truda st., 8, Sarapul, Udmurt Republic, Russia, 427960

E-mail: jaramo@mail.ru 